HEALTH PSYCHOLOGY REPORT · VOLUME 8(3), 2020 ORIGINAL ARTICLE
Joanna Dymecka (D)

$1 \cdot \mathrm{A}, \mathrm{B}, \mathrm{C}, \mathrm{D}, \mathrm{E}, \mathrm{F}$

Ilona Bidzan-Bluma $\mathbb{D}$

$2 \cdot \mathrm{A}, \mathrm{B}, \mathrm{E}, \mathrm{F}$

Monika Bidzan (D)

$3 \cdot \mathrm{A}, \mathrm{C}, \mathrm{D}, \mathrm{E}$
Anna Borucka-Kotwica

$2 \cdot \mathrm{A}, \mathrm{B}$

Pawet Atroszko (D)

$2 \cdot \mathrm{A}, \mathrm{C}, \mathrm{D}$

Mariola Bidzan (D)

$2 \cdot A, B, C, D, E, G$

\title{
Validity and reliability of the Polish adaptation of the Health-Related Hardiness Scale- the first confirmatory factor analysis results for a commonly used scale
}

\begin{abstract}
BACKGROUND
The Health-Related Hardiness Scale (HRHS) developed by Pollock is one of the most widely used measures to assess the construct of hardiness in chronic diseases. However, the original structure of the scale has been investigated only with exploratory factor analysis, and there have been no studies investigating the structure of the scale using a confirmatory approach, so significant doubts about the validity of the scale could be raised.
\end{abstract}

PARTICIPANTS AND PROCEDURE

A total of 450 participants took part in the study, with the majority suffering from chronic diseases. A Polish version of the HRHS, the Sense of Coherence questionnaire (SOC-29), the Resiliency Assessment Scale (SPP-25), the Liverpool Scale of Sense of Self Efficacy (LSES), and the Acceptance of Illness Scale (AIS) were used. Confirmatory factor analyses (CFA) to assess factor structure of the HRHS and correlational analyses to investigate criterion validity were conducted. Since the original structure did not fit the data adequately, a modified structure of the short version of the scale was investigated and a good fit to the data was obtained.

\section{RESULTS}

The modified version consisted of two subscales of Control (6 items) and Challenge/Commitment (6 items) which had good Cronbach's $\alpha$ reliability, .75 and .75 respectively, and .83 for the overall score. The HRHS showed expected correlation patterns with criterion variables. Separate sten norm were provided for female and male patients with chronic illnesses.

\section{CONCLUSIONS}

The Polish version of the HRHS is a useful and valuable tool for assessing levels of health-related psychological hardiness. The scale can be used for both clinical and research purposes.

\section{KEY WORDS}

chronic illness; health-related hardiness; adaptation; confirmatory factor analyses

ORganization - 1: Institute of Psychology, University of Opole, Opole, Poland · 2: Institute of Psychology, University of Gdansk, Gdansk, Poland · 3: Faculty of Health Sciences, Medical University of Gdansk, Gdansk, Poland aUthors' Contributions - A: Study design - B: Data collection - C: Statistical analysis - D: Data interpretation .

E: Manuscript preparation · F: Literature search · G: Funds collection

CORRESPonding AUthor - Joanna Dymecka, Ph.D., Institute of Psychology, University of Opole, 1 Staszica Square,

45-052 Opole, Poland, e-mail: jdymecka@uni.opole.pl

to CITE this ARTICLE - Dymecka, J., Bidzan-Bluma, I., Bidzan, M., Borucka-Kotwica, A., Atroszko, P., \& Bidzan, M. (2020).

Validity and reliability of the Polish adaptation of the Health-Related Hardiness Scale - the first confirmatory

factor analysis results for a commonly used scale. Health Psychology Report, 8(3), 248-262. https://doi.org/10.5114/

hpr.2020.95746

RECEIVED 18.04.2020 • REVIEWED 05.05.2020 • ACCEPTED 06.05.2020 • PUBLISHED 27.05.2020 


\section{BACKGROUND}

Health-related hardiness is an important construct in health psychology (Kobasa, 1979, 1982; Pollock, 1999). The Health-Related Hardiness Scale (HRHS) developed by Pollock (1986) is the most commonly and widely used psychometric tool for measuring it. Thus far, it has been applied in research across the world (Pollock, 1999). However, the original structure of the scale has been investigated only with exploratory factor analysis (Pollock, 1986) and to date there have been no studies investigating the structure of the scale using a confirmatory approach (see Pollock 1999). Therefore, significant doubts about the validity of the scale could be raised. Taking into account the popularity of the scale in health-related psychological research, this is an important issue which needs to be addressed. To overcome this drawback, the aim of the current study is to investigate the factorial structure of the scale in clinical samples, as well as to investigate its criterion validity and to provide norms for the Polish population of chronically ill individuals.

Psychological hardiness is a construct proposed by Kobasa $(1979,1982)$ and Maddi (1999a, 1999b, $2002,2004)$ to describe a generalized style of an individual's functioning characterized by high levels of commitment, control, and challenge which alleviate the negative consequences of stress (Hystad, Eid, Laberg, Johnsen, \& Bartone, 2009; Hystad, Eid, Johnsen, Laberg, \& Bartone, 2010). Psychological hardiness is a cognitive-emotional set of three features. The first is commitment, i.e. the belief that one's life has purpose and is interesting, valuable, and meaningful. Committed individuals have a sense of purpose, invest a lot in themselves and their social relations, do not give up easily under pressure, and do not isolate themselves as a result of stress. Another feature of psychological hardiness is control - related to the belief that one can influence one's life events and modify stressors through one's own efforts. The last feature comprising psychological hardiness - challenge - mirrors the belief that changes are not a threat to an individual's personal safety, but may be an opportunity for development and growth. This is the belief that one may benefit from both successes and failures (Harris, 2004; Kobasa, Maddi, \& Kahn, 1982; Maddi et al., 2006; Maddi \& Kobasa, 1984; Tatarsky, 1993).

Psychological hardiness is a resource which has an important influence on human health. It is suggested that hardiness is one of the more important personality features, which modifies the negative influence of stress on health (Ghafourian-Boroujerdnia, Shiravi, Hamid, Hemmati, \& Kooti, 2014); this is why this feature is particularly important in cases of chronic illnesses (Ahmadi \& Vahedi, 2013; Brooks, 2003). In the 1980s, Pollock (1984) proposed the concept of health- related psychological hardiness. She started her research by studying adaptation to chronic diseases such as diabetes, hypertension, or rheumatoid arthritis. Pollock (1989) reported that hardiness was associated with better psychological adaptation to illness. It was also shown that individuals with high levels of hardiness exhibited lower levels of psychological stress and higher quality of life (Farber, Schwartz, Schaper, Moonen, \& McDaniel, 2000).

In line with the theoretical concept, psychological hardiness is associated with resources such as sense of coherence (Almedom, 2005; Antonovsky, 2005; Sullivan, 1989), which has been shown in multiple studies (Kravetz, Drory, \& Florian, 1993; Newton, 1999; Skirka, 2000). The theoretical concept also suggests that some of the features indicative of psychological hardiness, such as benefitting from both successes and failures, treating life as a challenge, and openness and flexibility (Kobasa et al., 1982; Maddi \& Kobasa, 1984; Tatarsky, 1993), may be associated with features of ego resiliency, proposed in the concept by Ogińska Bulik and Juczyński (2008).

Moreover, most studies show a relationship between psychological hardiness and sense of selfefficacy (Bernard, Hutchison, Lavin, \& Pennington, 1996; Chroni, Hatzigeorgiadis, \& Theodorakis, 2006; Hashemi, Kooshesh, \& Eskandari, 2015; May, Sowa, \& Niles, 1993; Oman \& Duncan, 1995). Many studies have also shown that health-related psychological hardiness is significantly related to adaptation to illness (Pollock, 1986, 1989, 1993; Pollock \& Duffy, 1990).

Pollock (1986) developed the HRHS, based on the definition proposed by Kobasa (1979), as a tool for measuring psychological hardiness in individuals with health problems. The scale contains 34 test items which are assessed by the participant on a 6-point Likert-like scale, where 1 indicates complete disagreement and 6 indicates complete agreement. Some items are reverse-scored. A participant can score between 34 and 204 points on the HRHS. The higher the score, the higher are the levels of health-related psychological hardiness. Apart from the overall levels of health-related psychological hardiness, the scale also measures its three components: control, commitment, and challenge. The control subscale consists of 14 items. Participants may score between 14 and 84 points on this subscale. The commitment subscale consists of 7 items and it is possible to score between 7 and 42 points on this scale. The challenge subscale consists of 13 items and the participant can score between 13 and 78 points. The original version of the scale was based on the results of exploratory factor analysis and showed good reliability.

Based on the theoretical assumptions and previous studies it is hypothesized that (H1) the HRHS has hierarchical factor structure with three factors reflect-
Polish adaptation of the HealthRelated Hardiness Scale 
Joanna Dymecka, Ilona BidzanBluma, Monika Bidzan, Anna Borucka-Kotwica, Paweł Atroszko, Mariola Bidzan ing control, commitment, and challenge loading on one general factor of hardiness. Taking into account the theoretical relationships between psychological hardiness and other psychological resources, as well as variables associated with health and coping with illness, it is hypothesized (H2) that there is a positive relationship between health-related hardiness and sense of coherence, self-efficacy, ego resiliency and adaptation to illness. In line with the concepts of Antonovsky $(2005)$ and Kobasa $(1979,1982)$ it is hypothesized (H3) that the strongest relationship should be observed between psychological hardiness and sense of coherence.

\section{PARTICIPANTS AND PROCEDURE}

\section{PARTICIPANTS}

Samples were gathered for the purposes of specific research projects on particular diseases, and combined for the purpose of this study. They do not represent a population of patients; however, they constitute a diverse sample including patients suffering from a variety of diseases which impair psychosocial functioning in different levels and manners. As such, it can be expected that they assure high variance of results of studied variables.

Table 1

Descriptive data for the sample $(N=450)$

\begin{tabular}{lcc}
\hline & $n$ & $\%$ \\
\hline Diagnosis & & \\
$\quad$ Multiple sclerosis & 137 & 30.44 \\
Thyroid cancer & 30 & 6.67 \\
Other chronic disease & 64 & 14.22 \\
Healthy participants & 219 & 48.67 \\
Gender & & \\
Female & 250 & 55.56 \\
Male & 200 & 44.44 \\
Education & & \\
During education & 7 & 1.55 \\
Primary school & 3 & 0.67 \\
Vocational school & 37 & 8.22 \\
High school & 141 & 31.33 \\
Bachelor's degree & 21 & 4.67 \\
Master's degree & 147 & 32.67 \\
Lack of data & 94 & 20.89 \\
\hline
\end{tabular}

A total of 450 individuals took part in the study, including 137 (30.44\%) diagnosed with multiple sclerosis, 30 (6.67\%) diagnosed with thyroid cancer, $64(14.22 \%)$ diagnosed with other chronic illnesses, and 219 (48.67\%) healthy individuals. Among the participants there were $250(55.56 \%)$ women and $200(44.44 \%)$ men. The mean age of the participants was 42.59 , with the youngest being 18 years old and the oldest 82 years old. The majority of participants had a master's degree $(32.67 \%)$ or high school education (31.33\%). Table 1 shows descriptive data for the sample.

\section{RESEARCH METHODS}

Health-Related Hardiness Scale. The Health-Related Hardiness Scale was developed by Pollock (1986) as a tool for measuring psychological hardiness in individuals affected by health problems. It contains 34 items which participants assess on a 6-point Likert scale where 1 indicates complete disagreement and 6 indicates complete agreement. Some items are reverse-scored. A participant may score between 34 and 204 points on the HRHS. The higher the score, the higher are the levels of health-related psychological hardiness. As well as overall levels of health-related psychological hardiness, the scale also measures its three components: control (14 items), commitment (7 items), and challenge (13 items). Cronbach's $\alpha$ for the original version of the HRHS was .91, for control it was .81, for commitment it was .62 and for challenge it was .80 .

Sense of Coherence questionnaire. The Sense of Coherence questionnaire SOC-29 measures the sense of coherence. The questionnaire consists of 29 items which refer to different aspects of human life. Participants assess them on a 7-level semantic scale with bi-polar extreme points. Some items are reverse-scored. The overall score is calculated by summing up the points from separate items (Antonovsky, 1987; Polish adaptation Pasikowski, 2001). The questionnaire is used to measure global sense of coherence as well as its three components: comprehensibility, manageability, and meaningfulness. The reliability coefficient for the Polish version of the SOC-29 equals .88 .

Resiliency Assessment Scale. The Resiliency Assessment Scale (SPP-25) by Ogińska-Bulik and Juczyński (2008) assesses the resiliency of adult individuals, both sick and healthy. It consists of 25 items forming 5 subscales measuring 5 factors: determination and persistence in action, openness to new experiences and sense of humour, personal competence, and tolerance for negative affect, tolerance for failures and treating life as a challenge, and optimistic attitude towards life and the ability to mobilise oneself in difficult situations. All items are assessed on a 5-level 
Likert-like scale, where 0 indicates strongly disagree, 1 - somewhat disagree, 2 - neither agree or disagree, 3 - somewhat agree, and 4 - strongly agree. Results are calculated for the whole scale and for the separate subscales. The higher the score, the higher are the levels of ego resiliency. This scale is characterized by high internal validity, and the Cronbach's $\alpha$ for the scale equals 89 .

Liverpool Self-Efficacy Scale. The Liverpool SelfEfficacy Scale (LSES) assesses sense of self-efficacy in individuals suffering from multiple sclerosis; the Polish adaptation of the scale was developed by Dymecka, Bidzan, and Gerymski (2020). This scale is composed of two subscales: control (6 items) and personal agency (5 items). Participants assess the 11 items on a 4-point Likert-like scale where 1 indicates I strongly agree, 2 - I agree, 3 - I disagree, and 4 - I strongly disagree. Some items are reverse-scored. The higher the score, the higher is the patient's sense of efficacy. The reliability of the Polish version of the questionnaire was assessed using Cronbach's $\alpha$ coefficient, which was equal to .81 .

Acceptance of Illness Scale. The Acceptance of Illness Scale (AIS), developed by Felton, Revenson, and Hinrichsen (1984) and adapted by Juczyński (2001), assesses a patient's adaptation to limitations caused by illness. It contains 8 items describing consequences of poor health. Each item is assessed by the participant on a 5-level Likert-like scale, ranging from 1 (I strongly agree) to 5 (I strongly disagree). A low score indicates lack of acceptance of the illness and a strong sense of psychological discomfort. A high score indicates acceptance of the illness and lack of negative emotions associated with it. The higher the acceptance of the illness, the better is the adaptation to it. The reliability of the Polish version of the scale is satisfactory, with Cronbach's $\alpha$ equal to .85 .

\section{PROCEDURE}

Language analysis of the scale was performed in accordance with the adaptation strategy. The original questionnaire was translated into Polish by two translators (psychologists, who are English teachers) independently. Next, the translators settled upon the best Polish version, which was then subjected to back translation (into English) done by a native speaker who had not seen the original version. A bilingual translator assessed the compliance of the back translation with the original.

Then, the Polish version was assessed with regards to the validity of the items. After a positive assessment, the final version was used in the study. Research took place in the years 2015-2016. Participants gave informed consent before participating in the study. They were informed about the aims of the study, that participation was anonymous, and that all data would only be used for research purposes. All participants gave consent to participate in the study, which consisted of filling in a set of questionnaires.

\section{FACTOR ANALYSIS}

A confirmatory factor analysis (CFA) was used to investigate the goodness of fit of the measurement model. The original hierarchical model consisting of three first-order factors (commitment, control, challenge) and one second-order factor (hardiness) of the HRHS was tested. Lack of correlation between error terms of the items was assumed. The CFA of the Polish version of the scale showed an overlap of challenge and commitment factors which resulted in combining them into one factor. Therefore, in the second model, two first-order factors (challenge/commitment and control) and one second-order factor (hardiness), congruent with previous analyses (Pollock \& Duffy, 1990), were assumed. In the second model, items with low factor loadings $(<.40)$ were eliminated. In order to improve model fit, an analysis of modification indices was performed. Items which had the highest covariance of the error terms with other items were eliminated. Furthermore, items which had low factor loadings $(<.40)$ after these modifications were introduced were also eliminated. The final model assumed two first-order factors (challenge/commitment and control) and one second-order factor (hardiness) with no correlation of error terms. The maximum likelihood estimation method was used. The following measures were used to evaluate fit of the model: $\chi^{2}$ divided by degrees of freedom $\left(\chi^{2} / d f\right)$, comparative fit index (CFI), Tucker-Lewis index (TLI), and root mean squared error of approximation (RMSEA). Cutoff scores used were: $\chi^{2} / d f \leq 5, \mathrm{CFI} \geq .90$, TLI $\geq .90$, and RMSEA $\leq .06$ to .08 (Brown, 2015; see Hu \& Bentler, 1999; Schreiber, Nora, Stage, Barlow, \& King, 2006). AMOS version 24.0 was used.

\section{STATISTICAL ANALYSES}

Means, standard deviations, and minimum and maximum scores for all participants (who were divided into groups based on their health status) were calculated. In order to examine the associations between hardiness, control, challenge/commitment, and other studied variables, Pearson's correlation coefficients were calculated. For the purpose of calculating sten scores, Student's $t$-test for independent groups was performed, in which participants' hardiness and its components (control, challenge/commitment) were compared based on health condition and gender. All tests were two-tailed and the significance level was set to $\alpha=.05$. In order to investigate whether age is a relevant variable in terms of calculating sten scores for the
Polish adaptation of the HealthRelated Hardiness Scale 
Joanna Dymecka, Ilona BidzanBluma, Monika Bidzan, Anna Borucka-Kotwica, Paweł Atroszko, Mariola Bidzan
HRHS, correlation coefficients between age and hardiness, control, as well as challenge/commitment were calculated. Because age and health status were related to HRHS scores, participants were divided into four groups (healthy females, females with chronic diseases, healthy males, and males with chronic diseases), and correlations were calculated separately for each of these four groups. Sten scores based on percentiles (to accommodate for any non-normality of distribution in raw scores) were calculated for individuals with a diagnosis of chronic disease. All statistical analyses were conducted in IBM SPSS 24.

\section{ETHICS}

The research was approved by the Research Ethics Committee. All participants consented to taking part in the study.

\section{RESULTS}

\section{FACTOR ANALYSIS}

Table 2 shows fit indexes for all tested models. A model with three first-order factors and one second-order factor gave an inadmissible solution, suggesting that the model did not fit the data. Analysis of estimates showed overlap between challenge and commitment factors. Therefore, a two factor solution in which factors 2 and 3 were combined into one factor was investigated. The model with two first-order factors and one second-order factor did not have acceptable fit to the data. The standardized regression weights ranged from .12 to .63 (see Table S1 in Supplemental Material). The loading of challenge/commitment on hardiness was .89 , and the loading of control on hardiness was .78. Due to the lack of acceptable model fit, items $3,4,5,7,8,18,20$, 26, which had low factor loadings $(<.40)$, were eliminated. After elimination of these items, the model still did not have acceptable fit to the data (see Table 2). The standardized regression weights ranged from .42 to .64 (see Table S1 in Supplemental Material). The loading of challenge/ commitment on hardiness was .89, and the loading of control on hardiness was .75. On the basis of modification indices, items with the highest covariances of residuals with other items $(2,6,13,14,21,27,28,30$, $31,32,33)$ were eliminated one at a time. During these modifications, two items (9 and 12) with low factor loadings were also eliminated. At each step, Cronbach's $\alpha$ reliability coefficients were calculated to balance between the validity and reliability of the scale. At the level of reaching the threshold for minimally acceptable fit of the model to data (i.e. RMSEA $=.08$, $\mathrm{CFA}=.90, \mathrm{TLI}=.90)$, the scales consisted of 7 items each and the Cronbach's $\alpha$ reliability coefficients were
.77 for challenge/commitment, .76 for control, and .84 for the total scale. This procedure was continued until the final modified model had a very good fit to the data (see Table 2). Because the reliability coefficient did not significantly drop in comparison to the barely acceptable model, the final 6-items-per-factor model was assumed. The standardized regression weights ranged from .43 to .70 (see Table S1 in Supplemental Material). The loading of challenge/commitment on hardiness was .78 and the loading of control on hardiness was .97. Figure 1 shows the final model and the standardized regression weights for each of the twelve items. The Cronbach's $\alpha$ reliability coefficients for the final model were.75 for challenge/commitment, .75 for control, and .83 for the total scale. This model can be used in future research as it shows very good factorial validity and adequate reliability.

\section{DESCRIPTIVE STATISTICS}

Four hundred and fifty individuals took part in this study: 250 women $(55.6 \%)$ and 200 men (44.4\%), with mean age of $M=42.59(S D=15.83)$, range $18-82$ years. The sample comprised 219 participants with no diagnosis (48.67\%) and 231 participants with various diagnoses of chronic diseases (51.33\%): 137 with multiple sclerosis (30.44\%), 30 with thyroid cancer $(6.67 \%)$, and 64 with some other chronic disease (14.22\%). Table 1 shows descriptive data for the sample.

Table 3 presents minimum and maximum scores, mean scores, and standard deviations of hardiness and its components within each group.

Table 4 presents mean scores, standard deviations, and interrelationships between hardiness control, challenge/commitment, and other studied variables. The correlation patterns of hardiness and its two components with sense of coherence, self-efficacy, acceptance of illness, and psychological resilience were as expected. The challenge/commitment component showed slightly lower correlations with these criterion variables than the control component.

\section{NORMS OF THE REVISED HRHS}

Preliminary analyses showed that scores on the HRHS of women and men, as well as scores of participants in healthy group and the scores of participants in group with chronic diseases, differed significantly (Tables S2-S5 in Supplemental Material). For this reason, norms were developed for the latter group only, and separately for women and men. There was no relationship between scores on the HRHS and age (Table S6 in Supplemental Material); therefore, norms were not developed for different age categories. Norms for women and men with chronic diseases can be found in Table S7 (in Supplemental Material). 
Fit indexes for different models of Health-Related Hardiness Scale

\begin{tabular}{|c|c|c|c|}
\hline & $\begin{array}{l}\text { Two first-order } \\
\text { factors, one } \\
\text { second-order } \\
\text { factor }\end{array}$ & $\begin{array}{l}\text { Two first-order factors, one } \\
\text { second-order factor (after } \\
\text { elimination of the items } \\
\text { with low factor loadings) }\end{array}$ & $\begin{array}{l}\text { Two first-order factors, one second- } \\
\text { order factor (after elimination of } \\
\text { the items with correlation of error } \\
\text { terms) - minimally acceptable fit }\end{array}$ \\
\hline$\chi^{2} / d f$ & 4.09 & 4.09 & 2.69 \\
\hline RMSEA & .08 & .08 & .06 \\
\hline $\begin{array}{l}\text { RMSEA } \\
90 \% \mathrm{CI}\end{array}$ & $.08-.09$ & $.08-.09$ & $.05-.07$ \\
\hline SRMR & .09 & .08 & .05 \\
\hline CFI & .63 & .73 & .91 \\
\hline TLI & .61 & .70 & .90 \\
\hline $\begin{array}{l}\text { Cronbach's } \alpha \\
\text { Hardiness }\end{array}$ & .89 & .89 & .84 \\
\hline $\begin{array}{l}\text { Cronbach's } \alpha \\
\text { Control }\end{array}$ & .81 & .82 & .76 \\
\hline $\begin{array}{l}\text { Cronbach's } \alpha \\
\text { Challenge/ } \\
\text { commitment }\end{array}$ & .85 & .85 & .77 \\
\hline
\end{tabular}

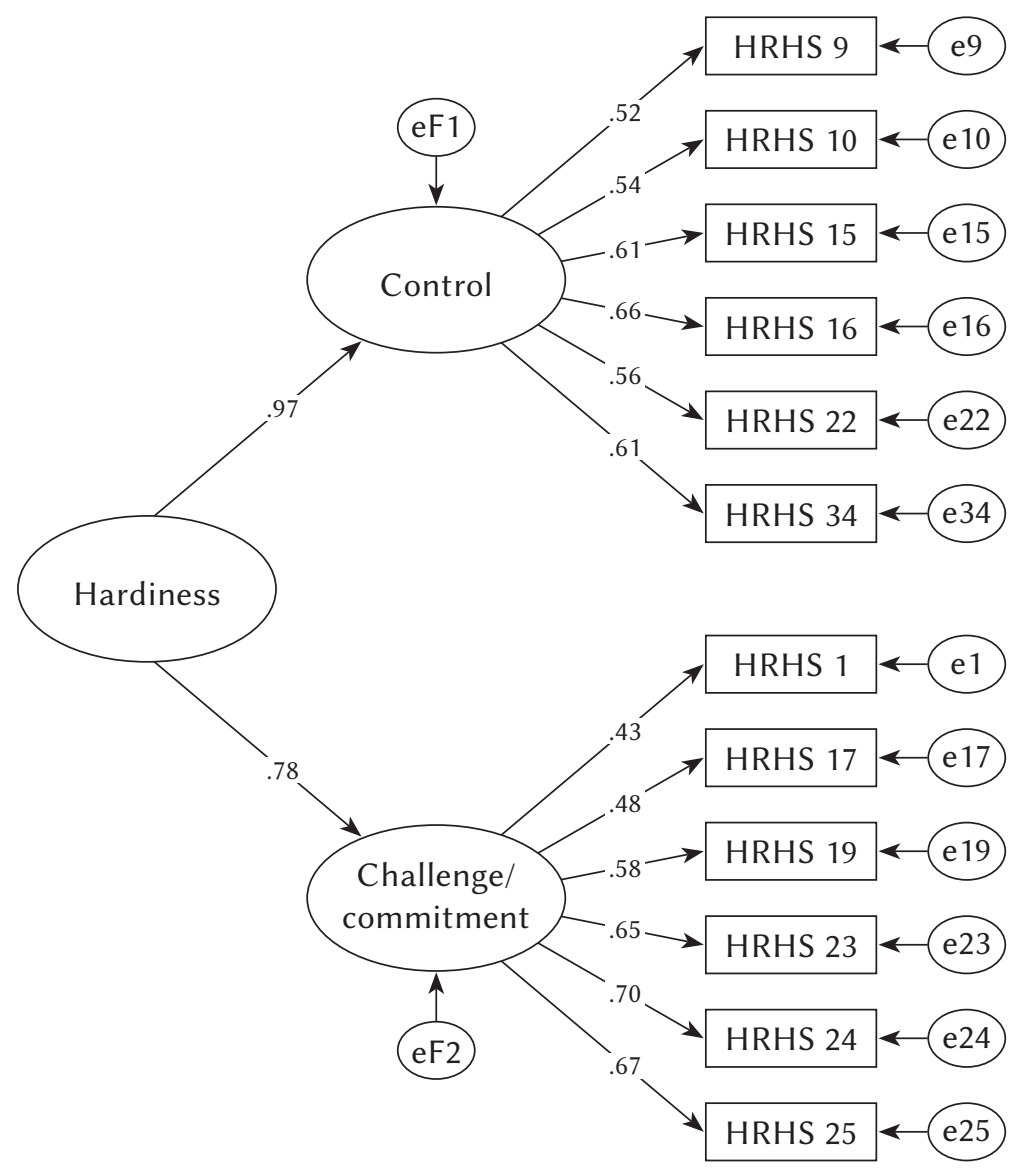

Figure 1. Factor structure and standardized loadings of items for the final version of the Health-Related Hardiness Scale. 
Table 3

Minimum and maximum scores, mean scores (M), and standard deviations (SD) of hardiness, control, and challenge/commitment within each group

\begin{tabular}{|c|c|c|c|c|c|c|}
\hline Group & $N / n$ & Variable & Min & Max & $M$ & $S D$ \\
\hline \multirow[t]{3}{*}{ All participants } & \multirow[t]{3}{*}{450} & Control & 6 & 36 & 23.56 & 5.72 \\
\hline & & Challenge/commitment & 8 & 36 & 25.40 & 5.47 \\
\hline & & Hardiness & 16 & 72 & 48.96 & 9.91 \\
\hline \multirow[t]{3}{*}{ Multiple sclerosis } & \multirow[t]{3}{*}{137} & Control & 6 & 36 & 21.35 & 6.14 \\
\hline & & Challenge/commitment & 8 & 36 & 24.65 & 6.11 \\
\hline & & Hardiness & 16 & 72 & 46.00 & 10.99 \\
\hline \multirow[t]{3}{*}{ Thyroid cancer } & \multirow[t]{3}{*}{30} & Control & 14 & 31 & 21.50 & 4.27 \\
\hline & & Challenge/commitment & 17 & 31 & 24.77 & 4.64 \\
\hline & & Hardiness & 33 & 62 & 46.27 & 7.54 \\
\hline \multirow{3}{*}{$\begin{array}{l}\text { Others chronic } \\
\text { diseases }\end{array}$} & \multirow[t]{3}{*}{64} & Control & 8 & 33 & 24.42 & 5.60 \\
\hline & & Challenge/commitment & 12 & 34 & 26.67 & 5.33 \\
\hline & & Hardiness & 22 & 64 & 51.09 & 9.78 \\
\hline \multirow[t]{3}{*}{ Healthy participants } & \multirow[t]{3}{*}{219} & Control & 6 & 36 & 24.96 & 5.15 \\
\hline & & Challenge/commitment & 12 & 36 & 25.58 & 5.13 \\
\hline & & Hardiness & 25 & 69 & 50.55 & 9.02 \\
\hline
\end{tabular}

Table 4

Mean scores $(M)$, standard deviations (SD), and correlations between studied variables $(n=117)$

\begin{tabular}{lccccccc}
\hline Group & $M(S D)$ & 2 & 3 & 4 & 5 & 6 & 7 \\
\hline 1. Hardiness & $48.96(9.91)$ & $.89^{* *}$ & $.88^{* *}$ & $.42^{* *}$ & $.31^{* *}$ & $.27^{* *}$ & $.38^{* *}$ \\
2. Control & $23.55(5.72)$ & & $.57^{* *}$ & $.44^{* *}$ & $.34^{* *}$ & $.30^{* *}$ & $.37^{* *}$ \\
3. Challenge/commitment & $25.40(5.47)$ & & & $.31^{* *}$ & $.22^{*}$ & $.18^{*}$ & $.32^{* *}$ \\
4. Sense of coherence & $130.84(29.61)$ & & & & $.56^{* *}$ & $.42^{* *}$ & $.68^{* *}$ \\
5. Self-efficacy & $27.65(5.88)$ & & & & & $.53^{* *}$ & $.41^{* *}$ \\
6. Acceptance of illness & $24.20(8.55)$ & & & & & & $.34^{* *}$ \\
7. Psychological resilience & $70.26(15.10)$ & & & & & & \\
\hline
\end{tabular}

Note. ${ }^{*} p<.05,{ }^{* *} p<.01$.

\section{DISCUSSION}

Factor-analytical results showed that the original model with three first-order factors and one secondorder factor gave an inadmissible solution, suggesting that the model did not fit the data and a two-factor solution in which factors 2 and 3 were combined into one factor was investigated (H1 not substantiated). The model with two first-order factors and one second-order factor did not have acceptable fit to the data and items with low factor loadings $(<.40)$ were eliminated. After elimination of these items, the model still did not have acceptable fit to the data. Further modifications were introduced until the final modified model had a very good fit to the data. Because the reliability coefficient did not significantly drop in comparison to the barely acceptable model, the final 6-items-per-factor model was assumed. The Cronbach's $\alpha$ reliability coefficients for the final model were .75 for challenge/commitment, .75 for control, and .83 for the total scale. This model is suggested for use in future research as it shows very good factorial validity and adequate reliability.

\section{CRITERION VALIDITY}

In line with the assumptions, this study found a positive relationship between results on the HRHS and results on other scales which measure personal resources, such as sense of coherence, ego resiliency, 
and self-efficacy, as well as with the results of the scale measuring adaptation to illness, which is also in line with previous research analysing relationships between these variables (H2 substantiated) (Bernard et al., 1996; Chroni et al., 2006; Hashemi et al., 2015; Kravetz et al., 1993; May et al., 1993; Newton, 1999; Oman \& Duncan, 1995; Pollock, 1986, 1989, 1993; Pollock \& Duffy, 1990; Skirka, 2000). The strongest relationship was observed between hardiness and sense of coherence, which is in line with Antonovsky (2005) and Kobasa's $(1979,1982)$ concepts (H3 substantiated).

The study also revealed that health status and gender differentiate the levels of health-related psychological hardiness. It was observed that healthy individuals are characterised by higher hardiness and control than individuals with chronic diseases, and that women scored higher than men on hardiness, commitment, and health. Based on these results, sten scores were calculated for chronically ill individuals, men, and women separately.

\section{STRENGTHS AND LIMITATIONS}

To the authors' knowledge this is the first study to investigate factorial structure of HRHS with a confirmatory approach. The results provide support for a two-factor shorter version of the scale. This significantly adds to the literature because it provides a short valid and reliable tool to measure healthrelated hardiness in patient populations. Because of the robust approach to analysing the structure of the HRHS, it can be expected that this version of the scale can be successfully replicated in other countries and cultures. This way it will improve the quality of research concerning this psychological construct, especially taking into account that it is one of the most frequently studied constructs in health psychology (Brooks, 2003; Eschleman, Bowling, \& Alarcon, 2010). Valid and reliable measures of criterion variables were used. The sample was diverse and fairly large, enabling testing of the relatively complex structure of the initial 34-item scale, theoretically assumed to reflect the hierarchical three-factor structure with one general factor of hardiness.

However, this study is not free from certain limitations, which should be taken into account when drawing conclusions and preparing future research. Most importantly, the short version of the scale still needs cross validation in independent samples both in Poland and in other countries and cultures.

\section{CONCLUSIONS}

The results of the study suggest that the Polish version of the Health-Related Hardiness Scale is a valid and reliable tool. The HRHS scale is a useful and valuable tool for assessment of psychological hardiness in individuals with health problems. To the authors' knowledge this is the first tool for measuring this construct in Poland and the first study to demonstrate factorial validity of the short version of the scale with confirmatory factor analysis. Separate norms for females and males from the population of Polish chronically ill patients are provided. Future research should further cross-validate the short version of the scale both in Poland and in other countries and cultures.

\section{RefERENCES}

Ahmadi, G. T., \& Vahedi, G. A. (2013). Comparison of psychological hardiness with mental health among male and female students. European Psychiatry, 28, 1. https://doi.org/10.1016/S0924-9338(13)77464-9

Almedom, A. M. (2005). Resilience, hardiness, sense of coherence, and posttraumatic growth: All paths leading to light at the end of the tunnel. Journal of Loss and Trauma, 10, 253-265. https://doi. org/10.1080/15325020590928216

Antonovsky, A. (1987). Unraveling the mystery of health. How people manage stress and stay well. San Francisco, CA: Jossey-Bass Publishers.

Antonovsky, A. (2005). Rozwiktanie tajemnicy zdrowia. Jak radzić sobie ze stresem i nie zachorować [Unraveling the mystery of health. How people manage stress and stay well]. Warszawa: Instytut Psychiatrii i Neurologii.

Bernard, L. C., Hutchison, S., Lavin, A., \& Pennington, P. (1996). Ego-strength, hardiness, self-esteem, self-efficacy, optimism, and maladjustment: Health-related personality constructs and the Big Five model of personality. Assessment, 3, 115-131. https://doi.org/10.1177/107319119600300203

Brooks, M. V. (2003). Health-related hardiness and chronic illness: a synthesis of current research. Nursing Forum, 38, 11-20. https://doi.org/10.1111/ j.0029-6473.2003.00011.x

Brown, T. A. (2015). Methodology in the social sciences. Confirmatory factor analysis for applied research (2nd ed.). New York: Guilford Press.

Chroni, S., Hatzigeorgiadis, A., \& Theodorakis, Y. (2006). Onsite coping in novice climbers as a function of hardiness and self-efficacy. Annals of Leisure Research, 9, 139-154. https://doi.org/10.1080/ 11745398.2006.10816426

Dymecka, J., Bidzan, M., \& Gerymski, R. (2020). Polska adaptacja Liverpoolskiej Skali Poczucia Wtasnej Skuteczności [Polish adaptation of the Liverpool Self-Efficacy Scale]. Unpublished manuscript.

Eschleman, K. J., Bowling, N. A., \& Alarcon, G. M. (2010). A meta-analytic examination of hardiness. International Journal of Stress Management, 17, 277-307. https://doi.org/10.1037/a0020476
Polish adaptation of the HealthRelated Hardiness Scale 
Farber, E. W., Schwartz, J. A., Schaper, P. E., Moonen, D. J., \& McDaniel, J. S. (2000). Resilience factors associated with adaptation to HIV disease. Psychosomatics, 41, 140-146. https://doi.org/10.1176/appi. psy.41.2.140

Felton, B. J., Revenson, T. A., \& Hinrichsen, G. A. (1984). Stress and coping in the explanation of psychological adjustment among chronically ill adults. Social Science \& Medicine, 18, 889-898. https://doi. org/10.1016/0277-9536(84)90158-8

Joanna Dymecka, Ilona BidzanBluma, Monika Bidzan, Anna Borucka-Kotwica, Paweł Atroszko, Mariola Bidzan

Ghafourian-Boroujerdnia, M., Shiravi, Z., Hamid, N., Hemmati, A. A., \& Kooti, W. (2014). The relationnal of Isfahan Medical School, 31, 1812-1820.

Hashemi, L., Kooshesh, Z., \& Eskandari, H. (2015). Role of family communication patterns in develship of hardiness and immune system cells. Jouropment of hardiness and academic self-efficacy in adolescents. Proceedings of the Multidisciplinary Academic Conference, 1-8.

Harris, S. M. (2004). The effect of health value and ethnicity on the relationship between hardiness and health behaviors. Journal of Personality, 72, 379-411. https://doi.org/10.1111/j.0022-3506.2004.00266.x

Hu, L. T., \& Bentler, P. M. (1999). Cutoff criteria for fit indexes in covariance structure analysis: Conventional criteria versus new alternatives. Structural Equation Modeling, 6, 1-55. https://doi.org/ 10.1080/10705519909540118

Hystad, S. W., Eid, J., Laberg, J. C., Johnsen, B. H., \& Bartone, P. T. (2009). Academic stress and health: exploring the moderating role of personality hardiness. Scandinavian Journal of Educational Research, 53, 421-429. https://doi.org/10.1080/00313830903180349

Hystad, S. W., Eid, J., Johnsen, B. H., Laberg, J. C., \& Bartone, P. T. (2010). Psychometric properties of the revised Norwegian dispositional resilience (hardiness) scale. Scandinavian Journal of Psychology, 51, 237-245. https://doi.org/10.1111/j.14679450.2009.00759.x

Juczyński, Z. (2001). Narzędzia w promocji i psychologii zdrowia [The tools of measurement in promotion and psychology of health]. Warszawa: Pracownia Testów Psychologicznych Polskiego Towarzystwa Psychologicznego.

Kobasa, S. C. (1979). Stressful life events, personality, and health: an inquiry into hardiness. Journal of Personality and Social Psychology, 37, 1-11. https:// doi.org/10.1037/0022-3514.37.1.1

Kobasa, S. C. (1982). Commitment and coping in stress resistance among lawyers. Journal of Personality and Social Psychology, 42, 707-717. https:// doi.org/10.1037/0022-3514.42.4.707

Kobasa, S. C., Maddi, S. R., \& Kahn, S. (1982). Hardiness and health: a prospective study. Journal of Personality and Social Psychology, 42, 168-177. https:// doi.org/10.1037/0022-3514.42.1.168

Kravetz, S., Drory, Y., \& Florian, V. (1993). Hardiness and sense of coherence and their relation to nega- tive affect. European Journal of Personality, 7, 233244. https://doi.org/10.1002/per.2410070404

Maddi, S. R. (1999a). The personality construct of hardiness: I. Effects on experiencing, coping, and strain. Consulting Psychology Journal: Practice and Research, 51, 83-94. https://doi.org/10.1037/10614087.51.2.83

Maddi, S. R. (1999b). Comments on trends in hardiness research and theorizing. Consulting Psychology Journal: Practice and Research, 51, 67-71. https:// doi.org/10.1037/1061-4087.51.2.67

Maddi, S. R. (2002). The story of hardiness: Twenty years of theorizing, research, and practice. Consulting Psychology Journal: Practice and Research, 54, 173-185. https://doi.org/10.1037/1061-4087.54.3.173

Maddi, S. R. (2004). Hardiness: an operationalization of existential courage. Journal of Humanistic Psychology, 44, 279-298. https://doi.org/10.1177/ 0022167804266101

Maddi, S. R., Harvey, R. H., Khoshaba, D. M., Lu, J. L., Persico, M., \& Brow, M. (2006). The personality construct of hardiness, III: Relationships with repression, innovativeness, authoritarianism, and performance. Journal of Personality, 74, 575-598. https://doi.org/10.1111/j.1467-6494.2006.00385.x

Maddi, S. R., \& Kobasa, S. C. (1984). The hardy executive: Health under stress. Homewood, IL: Dow JonesIrwin.

May, K. M., Sowa, C. J., \& Niles, S. G. (1993). Family environments as predictors of personality hardiness and self-efficacy. The Family Journal, 1, 131135. https://doi.org/10.1177/1066480793012003

Newton, S. E. (1999). Relationship of hardiness and sense of coherence to post-liver transplant return to work. Holistic Nursing Practice, 13, 71-79.

Ogińska-Bulik, N., \& Juczyński, Z. (2008). Skala Pomiaru Prężności (SPP-25) [The Resiliency Assessment Scale (SPP-25)]. Nowiny Psychologiczne, 3, 39-56.

Oman, R. F., \& Duncan, T. E. (1995). Women and exercise: an investigation of the roles of social support, self-efficacy, and hardiness. Medicine, Exercise, Nutrition \& Health, 4, 306-315.

Pasikowski, T. (2001). Kwestionariusz Poczucia Koherencji dla dorosłych (SOC-29) [The Sense of Coherence Questionnaire for adults (SOC-29)]. In H. Sęk \& T. Pasikowski (Eds.), Zdrowie - stres zasoby. O znaczeniu poczucia koherencji dla zdrowia [Health - stress - resources. The importance of the sense of coherence for health] (pp. 71-86). Poznań: Wydawnictwo Humaniora.

Pollock, S. E. (1984). Adaptation to stress. Texas Nursing, 58, 12-13.

Pollock, S. E. (1986). Human responses to chronic illness: Physiologic and psychosocial adaptation. Nursing Research, 35, 90-95.

Pollock, S. E. (1989). The hardiness characteristic: a motivating factor in adaptation. Advances in Nursing 
Science, 11, 53-62. https://doi.org/10.1097/00012272198901000-00009

Pollock, S. E. (1993). Adaptation to chronic illness: a program of research for testing nursing theory. Nursing Science Quarterly, 6, 86-92. https://doi.org/ 10.1177/089431849300600208

Pollock, S. E. (1999) Health-related hardiness with different ethnic populations. Holistic Nursing Practice, 13, 1-10. https://doi.org/10.1097/00004650-199 904000-00003

Pollock, S. E., \& Duffy, M. E. (1990). The Health-Related Hardiness Scale: Development and psychometric analysis. Nursing Research, 39, 218-222. https:// doi.org/10.1097/00006199-199007000-00008

Polish adaptation of the HealthRelated Hardiness

Schreiber, J. B., Nora, A., Stage, F. K., Barlow, E. A., \& King, J. (2006). Reporting structural equation modeling and confirmatory factor analysis results: a review. The Journal of Educational Research, 99, 323-338. https://doi.org/10.3200/JOER.99.6.323-338

Skirka, N. (2000). The relationship of hardiness, sense of coherence, sports participation, and gender to perceived stress and psychological symptoms among college students. The Journal of Sports Medicine and Physical Fitness, 40, 63-70.

Sullivan, G. C. (1989). Evaluating Antonovsky's Salutogenic Model for its adaptability to nursing. Journal of Advanced Nursing, 14, 336-342. https:// doi.org/10.1111/j.1365-2648.1989.tb03421.x

Tartasky, D. S. (1993). Hardiness: Conceptual and methodological issues. Journal of Nursing Scholarship, 25, 225-229. https://doi.org/10.1111/j.15475069.1993.tb00786.x 


\section{APPENDIX}

Joanna Dymecka,

Ilona Bidzan-

Bluma, Monika

Bidzan, Anna

Borucka-Kotwica,

Paweł Atroszko,

Mariola Bidzan

Health-Related Hardiness Scale (HRHS)

\begin{tabular}{|c|c|c|c|c|c|c|}
\hline $\begin{array}{l}\text { Please indicate how strongly you } \\
\text { agree with the following statements }\end{array}$ & $\begin{array}{l}\text { Strongly } \\
\text { disagree }\end{array}$ & Disagree & $\begin{array}{l}\text { Somewhat } \\
\text { disagree }\end{array}$ & $\begin{array}{l}\text { Somewhat } \\
\text { agree }\end{array}$ & Agree & $\begin{array}{l}\text { Strongly } \\
\text { agree }\end{array}$ \\
\hline $\begin{array}{l}\text { 1. Involvement in health promotion } \\
\text { activities is stimulating. }\end{array}$ & 1 & 2 & 3 & 4 & 5 & 6 \\
\hline $\begin{array}{l}\text { 2. My good health is largely } \\
\text { a matter of good fortune. }\end{array}$ & 1 & 2 & 3 & 4 & 5 & 6 \\
\hline $\begin{array}{l}\text { 3. No matter what I do, I'm likely to } \\
\text { get sick. }\end{array}$ & 1 & 2 & 3 & 4 & 5 & 6 \\
\hline $\begin{array}{l}\text { 4. Setting goals for health is } \\
\text { unrealistic. }\end{array}$ & 1 & 2 & 3 & 4 & 5 & 6 \\
\hline $\begin{array}{l}\text { 5. Most things that affect my } \\
\text { health happen to me by accident. }\end{array}$ & 1 & 2 & 3 & 4 & 5 & 6 \\
\hline $\begin{array}{l}\text { 6. Changes taking place in health } \\
\text { care will have no effect on me. }\end{array}$ & 1 & 2 & 3 & 4 & 5 & 6 \\
\hline $\begin{array}{l}\text { 7. I do not find it interesting to } \\
\text { learn about health. }\end{array}$ & 1 & 2 & 3 & 4 & 5 & 6 \\
\hline $\begin{array}{l}\text { 8. No matter what I do, If I am } \\
\text { going to get sick, I will get sick. }\end{array}$ & 1 & 2 & 3 & 4 & 5 & 6 \\
\hline $\begin{array}{l}\text { 9. I feel no need to try to maintain } \\
\text { my health because it makes no } \\
\text { difference anyway. }\end{array}$ & 1 & 2 & 3 & 4 & 5 & 6 \\
\hline $\begin{array}{l}\text { 10. The current focus on promotion } \\
\text { is a fad that will probably } \\
\text { disappear. }\end{array}$ & 1 & 2 & 3 & 4 & 5 & 6 \\
\hline $\begin{array}{l}\text { 11. No matter how hard I work to } \\
\text { promote health for society, it } \\
\text { never seems to improve. }\end{array}$ & 1 & 2 & 3 & 4 & 5 & 6 \\
\hline $\begin{array}{l}\text { 12. I have little influence over my } \\
\text { health. }\end{array}$ & 1 & 2 & 3 & 4 & 5 & 6 \\
\hline
\end{tabular}




\section{SuPPLEMENTAL MATERIAL}

\section{Table S1}

Standardized factor loadings for items in the model with two first-order factors and one second-order factor solution and its consecutive modifications

\begin{tabular}{|c|c|c|c|}
\hline & $\begin{array}{l}\text { Two first-order } \\
\text { factors and one } \\
\text { second-order } \\
\text { factor }\end{array}$ & $\begin{array}{l}\text { Two first-order factors and } \\
\text { one second-order factor } \\
\text { (after elimination of items } \\
\text { with low factor loadings) }\end{array}$ & $\begin{array}{l}\text { Two first-order factors and one } \\
\text { second-order factor (after elimina- } \\
\text { tion of items with correlation } \\
\text { of error terms) }\end{array}$ \\
\hline HRHS1 & .52 & .52 & .43 \\
\hline HRHS2 & .56 & .58 & - \\
\hline HRHS3 & .33 & - & - \\
\hline HRHS4 & .40 & - & - \\
\hline HRHS5 & .35 & - & - \\
\hline HRHS6 & .56 & .59 & - \\
\hline HRHS7 & .34 & - & - \\
\hline HRHS8 & .38 & - & - \\
\hline HRHS9 & .48 & .42 & .52 \\
\hline HRHS 10 & .56 & .55 & .54 \\
\hline HRHS11 & .50 & .50 & - \\
\hline HRHS 12 & .45 & .48 & - \\
\hline HRHS13 & .42 & .43 & - \\
\hline HRHS 14 & .54 & .55 & - \\
\hline HRHS15 & .55 & .53 & .61 \\
\hline HRHS 16 & .59 & .55 & .66 \\
\hline HRHS17 & .46 & .44 & .48 \\
\hline HRHS 18 & .12 & - & - \\
\hline HRHS 19 & .58 & .58 & .58 \\
\hline HRHS20 & .35 & - & - \\
\hline HRHS21 & .52 & .55 & - \\
\hline HRHS22 & .55 & .53 & .56 \\
\hline HRHS23 & .63 & .62 & .65 \\
\hline HRHS24 & .60 & .58 & .70 \\
\hline HRHS25 & .57 & .52 & .67 \\
\hline HRHS26 & .37 & - & - \\
\hline HRHS27 & .60 & .64 & - \\
\hline HRHS28 & .50 & .54 & - \\
\hline HRHS29 & .46 & .48 & - \\
\hline HRHS30 & .45 & .47 & - \\
\hline HRHS31 & .46 & .50 & - \\
\hline HRHS32 & .51 & .52 & - \\
\hline HRHS33 & .51 & .53 & - \\
\hline HRHS34 & .59 & .58 & .61 \\
\hline
\end{tabular}

Polish adaptation of the HealthRelated Hardiness Scale 
Table S2

Mean scores (M), standard deviations (SD) and Student t-statistics for differences between groups of healthy participants and participants with chronic diseases

\begin{tabular}{lccccc}
\hline Variable & \multicolumn{2}{c}{ Healthy $(n=219)$} & \multicolumn{2}{c}{ Chronic disease $(n=231)$} & \multirow{2}{*}{$t$} \\
\cline { 2 - 5 } & $M$ & $S D$ & $M$ & $5 D$ & $5.25^{* * *}$ \\
\hline Control & 24.96 & 5.15 & 22.22 & 5.92 & 0.70 \\
Challenge/commitment & 25.58 & 5.13 & 25.23 & 5.78 & $3.37^{* * *}$ \\
\hline
\end{tabular}

oanna Dymecka, Ilona BidzanBluma, Monika Bidzan, Anna Borucka-Kotwica, Paweł Atroszko, Mariola Bidzan

Note. ${ }^{* *} p<.001$.

Table S3

Mean scores (M), standard deviations (SD), and Student t-statistics for differences between groups of females and males

\begin{tabular}{lccccc}
\hline Variable & \multicolumn{2}{c}{ Females $(n=250)$} & \multicolumn{2}{c}{ Males $(n=200)$} & \multirow{2}{*}{$t$} \\
\cline { 2 - 5 } & $M$ & $S D$ & $M$ & $5 D$ & 1.53 \\
\hline Control & 23.92 & 5.67 & 23.10 & 5.67 & $5.02^{* * *}$ \\
Challenge/commitment & 26.54 & 5.00 & 23.97 & 5.70 & $3.67^{* * *}$ \\
Hardiness & 50.47 & 9.48 & 47.07 & 10.13 & 3.07 \\
\hline
\end{tabular}

Note. ${ }^{* * *} p<.001$.

Table S4

Mean scores (M), standard deviations (SD), and Student t-statistics for groups of females and males separately for groups of different health status

\begin{tabular}{|c|c|c|c|c|c|c|}
\hline & \multirow[t]{2}{*}{ Variable } & $M$ & $S D$ & $M$ & $S D$ & \multirow[t]{2}{*}{$t$} \\
\hline & & \multicolumn{2}{|c|}{ Females $(n=103)$} & \multicolumn{2}{|c|}{ Males $(n=116)$} & \\
\hline \multirow{4}{*}{$\begin{array}{l}\text { Health } \\
(n=219)\end{array}$} & Control & 25.66 & 5.23 & 24.34 & 5.01 & 1.90 \\
\hline & Challenge/commitment & 27.54 & 4.44 & 23.84 & 5.01 & $5.70^{* * *}$ \\
\hline & Hardiness & 53.20 & 8.40 & 48.19 & 8.92 & $4.27^{* * *}$ \\
\hline & & \multicolumn{2}{|c|}{ Females $(n=147)$} & \multicolumn{2}{|c|}{ Males $(n=84)$} & \\
\hline \multirow{3}{*}{$\begin{array}{l}\text { Chronic } \\
\text { disease } \\
(n=231)\end{array}$} & Control & 22.71 & 5.79 & 21.37 & 6.09 & 1.66 \\
\hline & Challenge/commitment & 25.84 & 5.26 & 24.14 & 6.48 & $2.05^{*}$ \\
\hline & Hardiness & 48.55 & 9.75 & 45.51 & 11.47 & $2.14^{*}$ \\
\hline
\end{tabular}

Note. ${ }^{*} p<.05,{ }^{* * *} p<.001$. 
Table S5

Mean scores (M), standard deviations (SD), and Student t-statistics for groups of healthy participants and participants with chronic disease separately for females and males

\begin{tabular}{|c|c|c|c|c|c|c|}
\hline & \multirow[t]{2}{*}{ Variable } & $M$ & $S D$ & $M$ & $S D$ & \multirow[t]{2}{*}{$t$} \\
\hline & & \multicolumn{2}{|c|}{ Health $(n=103)$} & \multicolumn{2}{|c|}{ Chronic disease $(n=147)$} & \\
\hline \multirow{4}{*}{$\begin{array}{l}\text { Females } \\
(n=250)\end{array}$} & Control & 25.66 & 5.23 & 22.71 & 5.79 & $4.13^{* * *}$ \\
\hline & Challenge/commitment & 27.54 & 4.44 & 25.84 & 5.26 & $2.68^{* *}$ \\
\hline & Hardiness & 53.20 & 8.40 & 48.55 & 9.75 & $3.93^{* * *}$ \\
\hline & & \multicolumn{2}{|c|}{ Health $(n=116)$} & \multicolumn{2}{|c|}{ Chronic disease $(n=84)$} & \\
\hline \multirow{3}{*}{$\begin{array}{l}\text { Males } \\
(n=200)\end{array}$} & Control & 24.34 & 5.01 & 21.37 & 6.09 & $3.67^{* * *}$ \\
\hline & Challenge/commitment & 23.84 & 5.01 & 24.14 & 6.48 & -0.35 \\
\hline & Hardiness & 48.19 & 8.92 & 45.51 & 11.47 & 1.79 \\
\hline
\end{tabular}

Polish adaptation of the HealthRelated Hardiness Scale

Table S6

Pearson correlation coefficients between hardiness, control, challenge/commitment, and age in the four groups of participants

\begin{tabular}{|c|c|c|c|}
\hline Health condition & Gender & Variable & Mean \\
\hline \multirow[t]{6}{*}{ Health } & Females $(n=103)$ & Control & -.10 \\
\hline & & Challenge/commitment & -.18 \\
\hline & & Hardiness & -.16 \\
\hline & Males $(n=116)$ & Control & -.07 \\
\hline & & Challenge/commitment & -.12 \\
\hline & & Hardiness & -.11 \\
\hline \multirow[t]{6}{*}{ Chronic disease } & Females $(n=147)$ & Control & -.02 \\
\hline & & Challenge/commitment & .08 \\
\hline & & Hardiness & .03 \\
\hline & Males $(n=84)$ & Control & -.04 \\
\hline & & Challenge/commitment & -.02 \\
\hline & & Hardiness & -.04 \\
\hline
\end{tabular}


Table S7

Sten scores for females and males with chronic disease

\begin{tabular}{|c|c|c|c|c|c|c|}
\hline \multicolumn{7}{|c|}{ Sten scores for females } \\
\hline \multirow{2}{*}{$\begin{array}{c}\text { Sten } \\
1\end{array}$} & \multicolumn{2}{|c|}{ Control } & \multicolumn{2}{|c|}{ Challenge/commitment } & \multicolumn{2}{|c|}{ Hardiness } \\
\hline & 0 & 10 & 0 & 11 & 0 & 27 \\
\hline 2 & 11 & 14 & 12 & 16 & 28 & 33 \\
\hline 3 & 15 & 16 & 17 & 20 & 34 & 39 \\
\hline 4 & 17 & 19 & 21 & 23 & 40 & 43 \\
\hline 5 & 20 & 21 & 24 & 26 & 44 & 48 \\
\hline 6 & 22 & 25 & 27 & 28 & 49 & 53 \\
\hline 7 & 26 & 28 & 29 & 30 & 54 & 57 \\
\hline 8 & 29 & 31 & 31 & 31 & 58 & 61 \\
\hline 9 & 32 & 33 & 32 & 32 & 62 & 63 \\
\hline 10 & 34 & 36 & 33 & 36 & 64 & 72 \\
\hline \multicolumn{7}{|c|}{ Sten scores for males } \\
\hline Sten & \multicolumn{2}{|c|}{ Control } & \multicolumn{2}{|c|}{ Challenge/commitment } & \multicolumn{2}{|c|}{ Hardiness } \\
\hline 1 & 0 & 7 & 0 & 9 & 0 & 18 \\
\hline 2 & 8 & 11 & 10 & 13 & 19 & 25 \\
\hline 3 & 12 & 14 & 14 & 17 & 26 & 31 \\
\hline 4 & 15 & 17 & 18 & 20 & 32 & 39 \\
\hline 5 & 18 & 21 & 21 & 24 & 40 & 46 \\
\hline 6 & 22 & 25 & 25 & 27 & 47 & 51 \\
\hline 7 & 26 & 27 & 28 & 30 & 52 & 57 \\
\hline 8 & 28 & 28 & 31 & 33 & 58 & 60 \\
\hline 9 & 29 & 31 & 34 & 34 & 61 & 63 \\
\hline 10 & 32 & 36 & 35 & 36 & 64 & 72 \\
\hline
\end{tabular}

